\title{
Present Status of Organic Fruit Growing in Europe
}

\author{
F.P. Weibel, A. Häseli, O. Schmid and H. Willer \\ Research Institute of Organic Agriculture (FiBL) \\ Ackerstrasse, P.O. Box \\ CH-5070 Frick \\ Switzerland
}

Keywords: fruit, organic, Europe, production, economics, market

\begin{abstract}
Organic fruit growing in Europe has experienced remarkable growth rates since the mid 1990's. Southern states, especially Italy, Spain and France have the largest land area with organic fruit, are also growing olives, citrus and chestnuts. Mainly increasing interest of supermarket chains is responsible for this buoyancy, but also the availability of better plant protection products e.g. granulosis virus and mating disruption against codling moth, and Neem oil against Rosy Apple Aphid. State subsidies varying from 600 to more than 1600 Euro /ha/y in the EU-countries (15) are less decisive for the conversion of top fruit production. Market share of organic table fruit is only 1 to $2 \%$, reaching 4 to $5 \%$ in Switzerland. For Switzerland, we estimate a market potential of around 12 to $15 \%$, which is already achieved with organic vegetables. In order to reach that percentage, better solutions for several key problems have to be found, e.g. control of scab, fire blight, sooty blotch, brown rot, weed management, fertilisation and crop load regulation. Also the assortment of organically produced "modern-standard" varieties is not satisfactory, in particular with stone fruit.

The economics of organic fruit growing is comparatively healthy, however, it depends on receiving a one third higher farm gate price for the product. In Switzerland the benefit of organic orchards is $16 \%$ higher compared to integrated fruit production; but labour hours exceed those of IFP by $7 \%$, due to blossom thinning by hand, manual weed control and mice control.

Supermarkets have a tendency to just "substitute" conventional with organic fruit if requiring organic fruit from disease susceptible varieties with no cosmetic blemishes. This can/does feed back to the growers resulting in "substitutional" production with disease and pest sensitive orchards managed with intensive "organic" spray and fertilisation programs. This certainly does not correspond with either the original concept of organic farming or with expectations of organic consumers. Thus, still a lot of development - also on the marketing side - has to be undertaken.
\end{abstract}

\section{INTRODUCTION}

Looking at the organic (fruit) production in Europe is not only a matter of production statistics, regulations and economy figures but has a meaningful historical background. Europe was the cradle of very central pioneers and movements during the exciting worldwide development of organic farming (Janik, 1991; Schaumann et al., 2002; Vogt, 1999; Vogt, 2000; Weibel et al., 2002). For example, IFOAM, «The International Federation of Organic Agriculture Movements» the global umbrella organisation of all significant organic organisations, was founded in Versailles, France, in 1972 and held its first scientific congress in Sissach, Switzerland in 1977. The European Union initiated a pioneer act by enacting the legislation on organic farming «regulation 2092/91» in 1991 (for a consolidated version see Council of the European Commission 2002) with an EU-wide official definition on organic/biological/ecological farming.

During the past 100 years or so, the manifestation of organic farming shifted from a movement that was predominantly characterized by charismatic leaders to a more and more socially, politically and scientifically accepted production system, based on 
numerous private, national and international regulations.

Since 1999 the Global Codex Alimentarius of the FAO has also covered organic agriculture. The Codex-guidelines are intended to guide and promote the establishment of definitions for organic agriculture and requirements for organic food labeling, to assist in their harmonisation in order to protect consumers and to facilitate international trade.

\section{GENERAL OVERVIEW ON ORGANIC FARMING IN EUROPE}

The data mentioned in this chapter originate from different sources. The different Eurostat (the EU's official data-publishing agency) databases do not yet contain data on organic production. The building of a coherent database was one of tasks of a FAIR research project ("Effects of the CAP-reform and possible further developments on organic farming in the EU" FAIR3-CT96-1794 2000). The results of this project are currently one of the main sources for EU-reports as e.g. "Organic Framing in the EU: Facts and Figures" (European Commission 2001). Other data sources are:

I. Organic Agriculture Worldwide 2002: Statistics and Future Prospects (Yussefi/Willer 2002)

II. Organic Food and Beverages World supply and major European Markets, International Trade Centre (ITC 1999)

III. The Organic Europe Homepage (SOEL 2000 ff.) - Country Reports;

IV. World Markets for Organic Fruit and Vegetables. International Trade Centre et al. (2001).

For the Farm Structural Survey (FFS) of EU it was agreed in 2000, to collect relevant organic data and it will therefore be possible to compare the structure of organic holdings with conventional ones by the year 2002 (European Commission 2001)

Organic agriculture is practised in most countries of the world, and its share of agricultural land and farms is increasing almost everywhere. According to a survey by Stiftung Oekologie \& Landbau there are currently 17 million hectares under organic management (Yussefi \& Willer, 2002). Europe ranks e second with a proportion of $24.1 \%$ of the global organic land behind Oceania (7.6 million ha, most of it is low intensity grazing land in Australia) and before Latin America (3.2 million ha, most in Argentina), North America (1.1 million ha), Asia 0.05 million ha) and Africa (0.02 million ha). In 2000 and 2001, the market value of organic products were estimated at 17.5 billion and 21 billion US-Dollars, respectively in 2001 (International Trade Centre 2002).

In the 15 EU-Member States, certified organic and in-transition area increased from 0.7 million hectares in 1993 to 4.140 million hectares in 2001 (FiBL-survey July 2002, provisional results for 31.12.2001, not yet finalised, Forschungsinstitut für biologischen Landbau 2002). The real booming phase started in 1996, which means that in 2001, $3 \%$ of the utilised agricultural area is estimated to be grown under organic conditions on $145^{\prime} 113$ farms ( $2 \%$ of all farms).

In 2001, Italy had the larges organic growing area with 1,1 million hectares (estimate; the regions Sicily and Sardinia account for approx. $50 \%$ of the whole of Italy) followed by Germany with 632'165 ha, UK 527'323 ha, Spain 485'079 ha and France 420 '000.

Above the EU-average of $3 \%$ are Liechtenstein and Switzerland (both not EUMember states) with 17 and 10 percent of organically used land, Austria with $8.7 \%$ Italy 7,1 and Finland with $6.8 \%$ each, Denmark with $6.2 \%$, Sweden with $6.3 \%$, The United Kingdom with 3.3 and Germany with $3.27 \%$. Other countries with significant organic production are the Czech Republic with $3.86 \%$ and Slovenia with $2.45 \%$.

The importance of individual marketing channels differs between the states. In Italy, Netherlands, Belgium, Germany, Greece and Spain, direct marketing and marketing via specialised shops dominate the organic sector. In Sweden, Denmark, Finland, the United Kingdom, Austria and Switzerland most of the sales are concentrated on supermarkets and non-specialised shops. There is a clear tendency that where organic products are mainly sold through supermarkets, due to the high level of professionalism and higher turnover of products, growth and market shares are, and will be, highest. The dis- 
advantage of this development for the organic growers is that they are under more pressure from "conventional" market laws with little or no specific tolerance for organic products.

\section{LEGISLATIVE ASPECTS AND GOVERNMENT SUPPORT}

Legislation at Community levels dates back to July 1991 when Council Regulation (EEC) No 2092/91 on organic production of agricultural products and foodstuffs was adopted. It was supplemented by Regulation (EC) No 1804/1999 to include livestock production. (Council of the European Union 2002).

With regards to imports from third countries, there are seven countries (Argentina, Australia, the Czech Republic, Hungary, Israel, Switzerland and New Zealand) authorised to export to the EU because their legislations on organic production is compatible with EU-Regulation No 2092/91.

The EU logo established by Regulation (EEC) No 331/2000 for organic products is optional, not compulsory for the operators.

Legislation in Article 2 of Regulation No 2078/92 and in Article 23(2) of Regulation No 1257/99 allows sustainable and explicit organic farmers to obtain considerably higher annual area based payments, over conventionally produced crops. Member States are allowed to exceed these amounts as state aids with defined conditions. In Switzerland, subsidies to agriculture were abandoned and replaced with direct payments that depend on the ecological performances of the farms (e.g., 800 Euros per hectare per year in general for integrated and organic farms; while purely organic farms receive an additional 800 euro per hectare per year for horticultural crops, 533 euro for arable land and 133 for pasture).

The differences in payments farmers receive from country to country can be substantial. In general, organic fruit farms subsidies are (far) too low to compensate for the necessary investments and economic risks during the transition period. Thus, for the fruit growers, good farm gate prices for the product and good market perspectives are and will remain the decisive reasons to convert to certified organic production.

Beside this, most countries are supporting organic farming by supporting research and extension, marketing efforts, etc. Various European Governments have launched action plans for organic farming. As part of these action plans, marketing of organic products, advisory service and consumer information is supported (Denmark, Sweden, Netherlands, Flanders, Ireland, France, some of the German federal states). As a follow up of the EU-conference on organic food and farming the European Commission is now preparing a European Action plan for organic farming.

\section{IMPORTANCE OF EUROPEAN FRUIT PRODUCTION}

The assessment of accurate data on fruit production is relatively difficult. As mentioned above, more accurate, crop specific statistical data can be expected in future years. The data presented here, originated from the sources mentioned above, when horticultural data were given, as well as from a poll (EUGROF European Group of Researchers in Organic Fruit, 2002) of members of EUGROF the "European Group of Researchers in Organic Fruit" (see last paragraph).

At the present time, organic fruit production is biggest in southern Europe (Table 1) with Italy the leader. However, starting in 1995-1997 Portugal, Spain, Greece and Turkey showed a tremendous boom in organic fruit production. The biggest land area in these countries is occupied with olive growing (19000, 82000, 12000 and 1000 hectares), followed by dry fruit production $(1800,33000,0$ and 21000 ha). However, top fruit production in these countries is increasing - relatively and absolutely - much more than in the central and northern parts of Europe.

The organically cultivated horticultural area is biggest in Italy with officially (Ministero delle Politiche Agricole 2000) 94 thousand ha of olives, 31 thousand ha of fresh fruit and 15 thousand ha of citrus. In South Tyrol there are 540 ha of intensive, table fruit production, predominantly pip fruit. In 2001, France and Spain witnessed a large 
increase in a transition to organic fruit production where $50 \%$ of the total fruit production area was in transition in 2001. Although often not specifically documented, similar situations can be observed in many of the southern countries because many holdings that are undergoing conversion since 1999 will be certified organic only in 2002. Such an intensity of production growth certainly needs very careful preparations on the marketing side in order to prevent potential low prices and dumping of commodities.

For the Northern countries it is even more difficult to find out the production data because there is a large proportion of direct selling from farms to shops. In Central and Northern Europe the land area grown with organic fruit and berries are less than 500 ha per country with Germany as an exception having 1700 ha. Apples and strawberries are the most important species in Mid- and North Europe. Due to higher disease pressure and production risks the expansion of organic fruit production is much lower than in the southern countries.

We estimate, that organic fruit production is between 1-2\% of the total production in most countries, reaching 4-5\% in Switzerland.

\section{STANDARDS AND PERMITTED PRODUCTS FOR ORGANIC FRUIT PRODUCTION}

The minimal legal standards for organic farming in Europe are drawn up in EUregulation 2092/91 on organic farming 2092/91 (Council of the European Commission, 2002). Switzerland has an ordinance on its own which is, however, approved by the EU. The majority of the organic producers are members of a private label organization. In certain countries (e.g. Germany or Italy) a vast number of organic labels is rather confusing in guiding the consumers. For this reason different attempts are ongoing to create easier to understand umbrella labels. Up to now, France, Spain, Denmark, Austria, Germany and Finland have created a state label to certify this lowest production level (e.g. "ab" = agriculture biologique in France, the "Biosiegel" in Germany). Switzerland is an exception because the private and traditional label of the organic association of growers, processors and traders "BIO-SUISSE" has an almost dominating status. Firstly, this fact strengthens considerably the unity and action power of the Swiss Organic Movement as well as for marketing for political activities. Secondly it renders any creation of a state label unnecessary.

Each EU-country is maintaining - beside the EU-regulation 2092/91 - it's national laws and organic registration rules for plant protection, animal husbandry, fertilization and food processing. This is the reason why the use of copper is allowed in most European countries (as it is in EU-regulation 2092/91), with the exception of Denmark and The Netherlands. This disequilibrium is causing serious production problems for organic fruit growers in these latter countries. The EUGROF group is presently putting together an overview list of all important registered organic plant protection products. Also, other important products will be listed that are useful in some European countries for organic fruit production as e.g. Neem oil, Quassin, Granulose Virus, Mating Disruption with pheromones or Calciumpolysulfide (Lime Sulphur). Apart from EU- or national legislations each private label organization can set up more - but not less restrictive requirements. In contrast to EU-regulation 2092/91, most private labels do not allow the same farm to produce both organic and conventional products. In Switzerland, the Research Institute of Organic Farming, contracted by BIO-SUISSE, is releasing yearly an input-list of the allowed products that is posted to all organic farmers (FiBL 2002). All products of this list have been tested for their compatibility with organic principles not only for their active compound(s) but also for their formulation additives. The latter wouldn't be possible without very strict secrecy contracts and a good confidential relation with the companies.

\section{STILL A NICHE MARKET}

As mentioned above, in some countries like The Netherlands, Germany and France the marketing of organic fruit is carried out predominantly by relatively small 
organic-, bio- or health-shops. Especially with fresh fruits and vegetables, these nonhomogeneous market structures demand that growers adopt flexible strategies in production, marketing and communication.

In most European countries the proportion of organically grown fruit is still less than $1 \%$ of the total fruit production. For Italy the estimation is $1-2 \%$, for The Netherlands $2 \%$ and for Switzerland 4-5\% market share. Nevertheless it means that organic fruit still is a niche market (EUGROF 2002, FiBL 2002b). Why is that so? Supermarkets are the main potential for the future market expansion, but organic fruit still is a "new" product. Thus, they have few skills in handling and advertising organic. Organic vegetables should be easier to replace conventional products. In Switzerland, a market share of $12-15 \%$ is already achieved for vegetables. Theoretically there should be no reason that there are less organic buyers for fruit than for vegetables. Thus, the longerterm estimations for the Swiss organic fruit market are optimistic and vary around 10$15 \%$.

\section{CHARACTERISATION OF THE EUROPEAN FRUIT PRODUCTION}

What might seem small on an absolute scale is from a relative point of view quite dramatic. In Switzerland, the organic fruit growing area increased almost 10-fold from 40 ha in the early 1990's to 390 ha in 2002 (Table 1) (Weibel, 2001). The majority of the increased production took place on recently converted conventional production orchards. For this reason many of these orchards contain scab sensitive varieties as Golden Delicious, Royal Gala etc. (but also the problems to keep those varieties scab free with natural products - are very widespread). In, high-density apple production orchards with M9-type rootstocks, it is not unusual to find tree densities of 1800-3000 trees per ha. Often there are specialized family enterprises with 8-30 ha orchards or mixed farm with $1-4$ ha orchards.

\section{WHY DO EUROPEAN FRUIT GROWERS HESITATE TO CONVERT TO ORGANIC PRODUCTION?}

There are two major reasons, that conventional and IFP (integrated fruit production?) fruit growers hesitate to convert to organic production: i) the organic fruit market is still new and not a highly professional industry yet as it exists for conventional fruit. Thus farmers, before undertaking high investment risks, wait for a more solid confirmation of the organic boom. ii) Secondly - although fundamental technical improvements were made since the early 1990's, the yield risk in organic fruit growing is still considerably higher than in IFP and goes along with average yield decreases of 15-30 $\%$ in organic systems.

The key-problems in converting from conventional to organic fruit growers include:

1. Variety Choice. Globally, the trend setting apple varieties (e.g., Braeburn, Fuji, Royal Gala, Pacific Rose, Pink Lady, ect.) are very scab sensitive. Thus, these varieties not suitable for organic production - at least in humid climates. On the other hand resistant varieties cannot (yet) fully compete with these mainstream varieties partly in terms of sensorial quality and storage capability. In addition, the introduction of any new variety in large-scale production is expensive. This large dilemma between market demands and sustainable production poses a difficult starting point for the expansion of organic apple production. Unfortunately the situation is even worse with stone fruit where resistance breeding is much slower compared with apple breeding.

2. Lack of Effective or Efficient Organic Approved Plant Protection Products. As a general rule, in the more humid (northern) production zones (>700 $\mathrm{mm}$ rainfall per year) diseases such as scab, fire blight, wood cancer, sooty blotch, monilia fruit rot are the key problems organic apples and pear growers struggle with, whereas insect and mite problems are more important in dryer (southern) growing regions. With the exception of Neem Oil (against Rosy Apple Aphid) and Lime Sulphur (against scab), both having a slight penetrating (systemic) effect there are no natural products with a curative effect. Thus, in situations of high disease or pest pressure direct organic plant protection 
measures often fail. The organic grower must depend on more natural and sometime indirect methods of pest control. These can be "costly" to set up, and more than one type will be needed. These include tolerant varieties, ecological compensation such as increased orchard biodiversity, lower planting densities, good sanitary removal of the disease and pest inoculum, measures to increase soil fertility such as cover crops and mulches in order improve the stress tolerance of the trees, etc.

3. Weed Control. With many orchards utilizing trees with dwarfing rootstocks the control of weed competition for water and nutrients is important for sufficient tree performance. Alternatives to herbicides such as mechanical tillage, mulching with bark or straw, weed maps, under-sown plants are expensive and labour intensive.

4. Tree Nutrition. The lack of rapidly plant available fertilizers, mainly in respect to Nitrogen, $\mathrm{Mg}$ and micro-element is by some growers and advisors thought to be the main reason for low yields in organic apple orchards. However, clear scientific evidence is not yet available. With apples, reduced tree performance was shown to be due to the relatively high dosages of sulphur (Ferree, 1979). McArtney, (2001) found up to $30 \%$ decreased rate in photosynthesis on sulphur treated Braeburn apple trees. Fertilizer companies are releasing better and more crop specific organic fertilizers. Nevertheless, the building up and maintenance of a high soil fertility and structural stability remains a key goal of organic (fruit) growing.

5. Fruit Thinning. In the absence of synthetic thinners, early blossom thinning is a major concern to achieve high quality and fruit yields. For the moment the best alternatives are the use of the rope machine (Bertschinger et al., 1998) or 2 to 3 applications of $2 \%$ Lime Sulphur (Kelderer et al., 2002) (not allowed in all European states).

6. Support of Research and Extension. For years, organic production, in particular with horticultural corps, was considered as "a not possible option for the industry". Consequently, the support in terms of research and extension was almost zero compared with the development efforts for other systems, e.g., integrated fruit production. Today, the situation is different. The potential for an organic fruit market and production is available. Worldwide, scientists and extension workers are increasing their input into organic or organic-usable projects. Such a trend certainly will help the development of the organic fruit industry as well as the more conventional production system.

\section{ECONOMICS OF ORGANIC FRUIT PRODUCTION}

Data on the economics of organic fruit growing in Europe are too rarely assessed and cannot be considered as really representative. Many organic farms with fruit production differ substantially from conventional farm in terms that they have e.g. a high proportion of direct selling, have a higher diversity of products and have higher labour input production costs, etc. Our assessments in Switzerland (14 organic fruit farms, (Weibel et al., 2002) and Southern Germany (10 organic fruit farms, Stockert, 2000), allow a reasonable comparison with an average conventional system.

The main reasons for higher production costs in organic fruit growing are associated with higher costs of labour for:

i) Plant protection: Natural products such as Neem Oil, clay powders, soaps (for mite and/or sooty blotch control), Granulosis Virus, Quassia and other special products are expensive;

ii) Weed control: Because organic growers work with the same weed sensitive rootstocks as in conventional systems, 30-40 additional hours per hectare are needed for hand hoeing to clean the area around the trees from weeds (if this wouldn't be done, heavy vole damages can occur) as well as the additional time and costs of mechanical tillage between rows of tress. Our experiments to find modern-type, productive rootstocks that can support more weed competition are still inconclusive and more work is needed.

iii) Hand work for blossom thinning: Many organic fruit farms spend 70-120 or more labour hours for blossom thinning to control biannual bearing and to increase fruit quality. Lime sulphur (where allowed) or the use of a special rope machine can reduce 
these costs.

iv) Vole control: As there are no organic rodenticides available, organic growers often spend more than 30 working hours per ha for mice control with traps and or special COx exhausters.

v) Tree material: The obligation to use certified organic trees for new orchards increases the costs of the orchard-set up by about $10 \%$ however, the tree quality of the few organic nurseries is not always satisfactory.

In our model calculation (Weibel et al., 2002) we conclude that even with different technical improvements, production costs will be 7-15\% higher per hectare and yields will be $10-20 \%$ in organic production compared to more conventional systems. Under this assumption organic fruit growing is depending on a considerable higher, an average one third, farm gate price for the product.

The fact that the farm gate price for organic fruit is 30 and more percent higher than conventional fruit can lead to a substantial higher selling price at the retail level because packers and retailers have to add their profit and cost margins on the product (usually 28-32 \% in Switzerland). Consumers, however, are not always willing to pay these excessive prices. In Switzerland, the retailers and supermarket chains have, therefore reduced their percentage margins towards the absolute margins they apply to conventional fruit. This resulted in a more situation where prices for organically grown fruits are usually only around 32-40\% (and only rarely up to $70 \%$ ) higher than for conventional fruit.

Another, important economic advantage for the growers is that the market is not saturated and retailers usually sell out rather quickly. Thus, the retailers have lower costs for storage, less storage risk for storage loss and are under less pressure to lower prices.

\section{PERSPECTIVES HAVE TO BE FORMED ACTIVELY}

More work is needed on marketing. There is a clear tendency for supermarkets to simply "substitute" conventionally produce fruits by organic fruits. So they demand the same requirements for the organic fruit as for conventional or integrated such as en-vogue varieties and perfect external quality. This market pressure is feeding back to the growers in a way that they also tend to practice a "substitutional" organic production e.g. rather by planting disease sensitive world-varieties rather than less known tolerant or resistant varieties. Also, some growers apply sprays for cosmetic reasons rather than for the necessity of plant health. Even though only natural inputs are used, the question arises whether this tendency is still in accordance with the idea - and with the consumer expectation - of organic farming.

In Switzerland, until today BIO-SUISSE (2002) could defend separate quality standards for organic fruit tolerating as e.g. some minor spots of scab, sooty blotch, healed insect damages or smaller fruit sizes. On the other hand skin colour prescriptions as a good indicator of inner fruit quality - are stricter than for conventional apples. A successful step towards better communication with the organic fruit consumers is that "Coop", the second biggest supermarket chain of Switzerland, has introduced a new marketing concept to ease the market introduction of unknown, mainly scab resistant apple varieties (Weibel and Grab, 2000). This concept is informing and guiding the apple consumer primarily by different taste groups, these groups are also visualized by different colours of the packing labels. The variety names remain but are of secondary importance.

In Switzerland, the described discussion on the developing sorting standards takes place at a yearly pre-harvest meeting among organic fruit growers and retailers. It is a very active communication effort and is a very awarding exchange, to set standards for the harvest and is a benefit of all partners (Weibel, 2001).

A challenge for the future is the globalisation of the organic fruit market. In the summer season, apple and pear fruit from "favourable-and-cheaper-to-grow-organic" countries such as New Zealand, Argentina or Chile can be seen very often in the European shops and super markets. Even if retailers would remain loyal to the local producers, globalisation is pressuring the organic fruit growers in Europe to be more efficient and 
produce a higher quality product.

RESEARCH ON ORGANIC FRUIT GROWING IN EUROPE

The "European Group of Researchers on Organic Fruit" EUGROF, founded in 2000 is the connecting network for researchers who are predominantly active in organic fruit research from 14 countries (Weibel, 2001b). Some of the EUGROF Members are part of Organic Research Institutes as e.g. Louis Bolk Institute in the Netherlands, GRAB in France or FiBL in Switzerland; others are from "conventional" agricultural research institutes such as e.g. VZL in Italy, which contribute to the development of organic production by specific projects as part of their mandate to address sustainability of all agricultural production systems. The purpose of EUGROF is the exchange and discussion of information in an annual meeting, but also within working groups, to create synergies to resolve better experimental tasks and sometimes also administrative or legislative jobs. There is a clear tendency that co-operation among researchers of organic and other institutions is increasing (in Switzerland e.g. with the Federal Research Institutes FAW and RAC) what we consider as a very positive development.

\section{ACKNOWLEDGMENTS}

We thank Dr. James D. Anderson for his great help improving English useage in the manuscript. We also thank our colleagues in the EUGROF (European Group of Researchers in Organic Fruit Growing) for providing insider information and data of the organic fruit production in their country.

\section{Literature Cited}

Bertschinger, L., Stadler, W., Weibel, F.P. and Schumacher, R. 1998. New methods for an environmentally safe regulation of flower and fruit set and of alternate bearing of the apple crop, p. 64-70, In M. Blanke, ed. Proceedings Second Workshop on Pome Fruit Quality, Vol. 466. Acta Hort, Bonn-Röttingen, Germany.

Council of the European Union 2002. COUNCIL REGULATION (EEC) No 2092/91 of 24 June 1991 on organic production of agricultural products and indications referring thereto on agricultural products and foodstuffs (OJ L 198, 22.7.1991, p. 1), 1991R2092 - EN - 23.03.2002 - 013.001 - 1, [online] Brussels, European Commission, The Eurolex Homepage (<http://europa.eu.int/eur-lex $>)$, Date given in Document 23.03.2002, [cited 2.8.2002]. Portable Document Format (PDF). Available from: http://europa.eu.int/eur-lex/en/consleg/pdf/1991/en_1991R2092_do_001.pdf

EUGROF European Group of Researchers in Organic Fruit 2002. Poll on organic fruit production acreage in different European countries among EUGROF members. Participants: Louis Bolk Institute (The Netherlands); Beratungsdienst Oekologischer Obstbau (Germany); Henry Doubleday Research Association (UK); GRAB (France); Danish Inst. Agric. Science (Denmark); Univ. of Agric. Science (Austria); Versuchszentrum Laimburg (Italy). Conducted by FiBL (F. Weibel), CH-Frick in May-July.

European Commission 2001. Organic Farming in the EU: Facts and Figures. Brussels, 2001. Available at http://europa.eu.int/comm/agriculture/qual/organic/facts_en.pdf

Ferree, D.C. 1979. Influence of pesticide on photosynthesis of crop plants. In: Photosynthesis and Plant Development. R. Marcelle, H. Clijsters and M. Van Poucke, Eds. W. Junk Publ., The Hague; pp. 331-341.

FiBL Forschungsinstitut für biologischen Landbau 2002. Hilfsstoffliste 2002. Zugelassene und empfohlene Hilfsstoffe für den biologischen Landbau / Liste des Intrants 2002. Available at http://www.fibl.ch/buehne/publikationen/pdfs/merkblaetter/1032_hilfsstoffliste.pdf

FiBL Forschungsinstitut für biologischen Landbau 2000b. Organic Farming in Europe Provisional Statistics 2001. Provisional results of a FiBL survey July 2002; continual updating. [online] Frick / Bad Dürkheim Forschungsinstitut für biologischen Landbau/ Stiftung Oekologie \& Landbau (SOEL), The Organic Europe net homepage (www.organic.europe.net). Date given in Document: July 2002, [cited 5.8.2002]. HTML-Format. Available at http://www.organic-europe.net/europe_eu/statistics.asp 
FiBL Forschungsinstitut für biologischen Landbau and Stiftung Oekologie \& Landbau: The Organic Europe Homepage (www.organic-europe.net). Frick, $\mathrm{CH}$, and Bad Dürkheim, D, 2000, 2001, 2002 [cited 7.8.2002]

International Trade Centre UNCTAD/WTO 1999. Organic food and beverages: World supply and major European markets, Geneva 1999. Book Info available at http://www.intracen.org/mds/sectors/organic/summary2.htm

International Trade Centre UNCTAD/WTO, Technical Center for Agricultural and Rural Cooperation, Food \& Agriculture Organization of the United Nations 2001. UNCTWorld markets for organic fruit and vegetables. Opportunities for developing countries in the production and export of organic horticultural products. [online]. Rome, Food and Agriculture Organisation FAO, Organic Agriculture at the FAO Homepage (http://www.fao.org/organicag). Date given in document 2001. [cited 5.8.2002). HTML-Format, available at http://www.fao.org/DOCREP/004/Y1669E/Y1669E00.HTM

International Trade Centre 2002. Overview world markets for organic food \& beverages (estimates) [online]. Geneva, International Trade Centre. The Organic Products homepage (http://www.intracen.org/mds/sectors/organic). Date given in Document: January 2002, [cited 5.8.2002]. PDF-Format. Available at: http://www.intracen.org/mds/sectors/organic/overview.pdf

Janik, J. (ed.) 1992. History of the Organic Movement, HortTechnology. 2, 262-283.

Kelderer, M., Casera, C. and Lardschneider, E. 2002. Leitfaden für den biologischen Obst- und Weinbau 2002. Versuchszentrum Laimburg, Post Auer, Italy.

Lindhard, H. and Callesen, O. 1999. Questionnaire on organic fruit and berry production in Europe. EUFRIN-Information: http://www.ctifl.fr/eufrin/organic.htm; 3 p.

McArtney, S. 2001. Phytotoxicity of Lime Sulphur applications (to be completed)

Ministry of Agriculture, Fisheries and Food - Technical Secretariat General Madrid (Spain) 2002. The Spanish Agrofood Sector and Rural Environment: Facts and Figures (6th edition): XVI. Organic Farming.

Ministero delle Politiche agricole (2001). http://www.politicheagricole.it/PRODUZIONE/AGRIBIO/Italia2000.htm

MOAN, Scientific Network on Organic Farming in the Mediterranean Countries. (http://www.organicmedit.org.) Organic Agriculture in Mediterranean Area: Status of Arts. Unpublished document, (no year given, data until 1999). 248 p.

Schaumann, W., G.E. Siebeneicher, and I. Lünzer. 2002. Geschichte des ökologischen Landbaus. first ed. Stiftung Ökologie und Landbau (SÖL), D-Bad Dürkheim. 202 p.

Stockert, T. 2000. Kostenkalkulation im ökologischen Apfelanbau. Report. Staatliche Lehr- und Versuchsanstalt für Wein- und Obstbau Weinsberg (Germany).

Vogt, G. 1999. Entstehung und Entwicklung des ökologischen Landbaus im deutschsprachigen Raum. Stiftung Ökologie und Landbau (SÖL), D-Bad Dürkheim. 399 p.

Vogt, G. 2000. Origins, Development and Future Challenges of Organic Farming, p. 708711, In: T. Alföldi, Lockeretz W., Niggli U., eds. 13th Int. Scientific Conference of IFOAM, Basel, Switzerland.

Weibel, F.P. and Grab, F. 2000. Sustainable production needs sustainable marketing: Evaluation of a new marketing concept to introduce organically grown scab (Venturia inaequalis) resistant apple varieties at the Swiss supermarket retailer Coop. In: T. Alföldi, W. Lockeretz and U. Niggli (eds.). Proceedings of the $13^{\text {th }}$ IFOAM Scientific Conference. 28-31 August 2000. Basel, Switzerland; p. 255-258.

Weibel, F.P. 2001. Organic fruit production in Switzerland: Research and development to resolve cultural, management, and marketing problems. American Journal of Alternative Agriculture 16:191-195.

Weibel, F.P. 2001b. European Group of Researchers in Organic Fruit founded. FiBL press communication. Available at http://www.fibl.ch/buehne/aktuell/stellungnahmen/eugrof/founded.htm

Weibel, F.P., Häseli, A. and Schmid, O. 2002. Organic fruit growing in the beginning of the 20th century. Compact Fruit Tree 35:77-82. 
Willer, H. 2002. Organic Farming in Europe. Recent Developments and Future Prospects [online]. The Envirowindows Homepage (eu.eea.int). European Environment Agency, Copenhagen, Denmark, Data given in Document: 15.7. March 2002. HTMLDocument. [cited 5.8.2002]. HTML-Document.

URL http://ewindows.eu.org/Agriculture/organic/Europe/organic/Europe/of_in_europe <http://ewindows.eu.org/Agriculture/organic/Europe/of_research_table>

Yussefi, M. and Willer, H. 2002. Ökologische Agrarkultur weltweit - Organic Agriculture World-Wide. Statistiken und Perspektiven - Statistics and Future Prospects (GermanEnglish), 4th edition, February 2002, SÖL-Sonderausgabe 74. Available at http://www.soel.de/inhalte/publikationen/s_74.pdf.

\section{Internet Sites}

BIO-SUISSE

http://www.bio-suisse.ch $(\mathrm{g}, \mathrm{f}, \mathrm{e})$

Codex Alimentarius Homepage http://www.codexalimentarius.net/

Coop http://naturaplan.coop.ch/d/natur/ (ge, fr)

FiBL Forschungsinstitut für biologischen Landbau / Research Institute of Organic Agriculture (FiBL) http://www.fibl.ch/

Food and Agriculture Organisation FAO http://www.fao.org/

Food and Agriculture Organisation FAO: Organic Farming WebSite http://www.fao.org/organicag/

IFOAM Accreditation Programme (IAP) http://www.ifoam.org/accredit/index.html

IFOAM Basic Standards for Organic Agriculture http://www.ifoam.org/standard/index.html

IFOAM, International Federation of Organic Movements http://www.ifoam.org/ (en)

International Federation of Organic Agriculture Movements (IFOAM) http://www.ifoam.org/

International Trade Centre http://www.intracen.org/

International Trade Centre: Organic Farming Web Site http://www.intracen.org/mds/sectors/organic/welcome.htm

International Trade Centre: Retail Sales with Organic Products, Compiled by ITC, January 2002, based on trade estimates [cited 9.7.2002] http://www.intracen.org/mds/sectors/organic/overview.pdf

Migros http://www.migros.ch (ge, fr)

Organic Europe Homepage http://www.organic-europe.net

Swiss Standards for Organic Agriculture: http://www.admin.ch/ch/d/sr/c910_18.html (ge, fr, it) 


\section{Tables}

Table 1. Production area, fruit species and subsidies for organic fruit and berry production in Europe (data sources: Lindhard and Callesen 1999, Weibel 2001).

\begin{tabular}{|c|c|c|c|}
\hline Country & Production area in ha & Species & Sources \\
\hline \multirow[t]{3}{*}{ Portugal } & $19 ’ 415$ & Olives & 1) \\
\hline & $1 ’ 815$ & Dried Fruit & \\
\hline & 692 & Fresh Fruit & \\
\hline \multirow[t]{4}{*}{ Spain } & $82 ’ 246$ & Olives & 3) and 5) \\
\hline & $33^{\prime} 100$ & Dried Fruit & \\
\hline & 3’424 & Fresh Fruit & \\
\hline & 909 & Citrus & \\
\hline \multirow[t]{3}{*}{ Italy } & $93 ’ 863$ & Olives & 4) Ministero \\
\hline & $31 ’ 364$ & Fruit. In South Tirol 540 ha pipfruit & politiche Italiana \\
\hline & $15^{\prime} 384$ & Citrus & and 5) \\
\hline \multirow[t]{3}{*}{ Greece } & $12 ’ 085$ & Olives & 1) and 2) and 5) \\
\hline & 196 & Currants & \\
\hline & 80 & Top Fruit & \\
\hline \multirow[t]{2}{*}{ Turkey } & $21 ’ 059$ & Dried Fruit incl. Nuts & 2) \\
\hline & 1971 & Fresh Fruit & \\
\hline \multirow[t]{5}{*}{ France } & 1'555 & Nuts & 5) and 2) \\
\hline & $1 ’ 280$ & Stone Fruit & \\
\hline & $1 ’ 255$ & Pipfruit incl. Cidre & \\
\hline & 490 & Olives & \\
\hline & 200 & Citrus & \\
\hline Switzerland & $\begin{array}{l}390 \text { (additionally } 6^{\prime} 000-8^{\prime} 000 \mathrm{t} \\
\text { per year pip fruit for organic } \\
\text { apple juice production from } \\
\text { high stem trees) }\end{array}$ & $\begin{array}{l}\text { Apple ( } 250 \text { ha), pears, apricot, cherries, } \\
\text { plums, diff. berries, kiwi }\end{array}$ & 6) \\
\hline Austria & 598 & Apples, currants, strawberries, pears, etc. & 7) \\
\hline$\underline{\text { Hungary }}$ & 650 & Top Fruit & 1) \\
\hline$\underline{\text { Poland }}$ & 284 & Top Fruit & 1) \\
\hline Belgium & 328 & Top Fruit (150 ha, $75 \%$ apple, $25 \%$ pear) & 5) \\
\hline Germany & $1 ’ 735$ & Excluding production on standard trees & 5) \\
\hline The Netherlands & $180+115$ in conversion & Apples, pears, strawberries & 5) \\
\hline \multirow[t]{2}{*}{ United Kingdom } & 604 & Top Fruit (estimated 514) & 5) \\
\hline & & Soft Fruit (estimated 90) & \\
\hline Denmark & 306 & $\begin{array}{l}\text { Black currants, strawberries, apples, } \\
\text { sweet cherries }\end{array}$ & 5) \\
\hline Norway & 57 & Apples, pears, plums, diff. berries & 7) \\
\hline Sweden & 189 & Strawberries, apples, other berries & 7) \\
\hline
\end{tabular}

1) Organic-Europe Homepage

2) MOAM

3) Ministry of Agriculture, Fisheries and Food, Spain 2002

4) Ministero Politiche Italiana 2001

5) Weibel 2002, Poll among members of EUGROF

6) Bio-Suisse 2001

7) Lindhardt and Callesen 1999 